\title{
FAIR TRADE COFFEE PRACTICES: APPROACHES FOR FUTURE SUSTAINABILITY OF THE MOVEMENT
}

\author{
Grant E. Helms \\ Actually, this seems to be the basic need of the human heart \\ in nearly every great crisis: a good, hot cup of coffee. \\ -Alexander King
}

\section{INTRODUCTION}

Coffee is one of the most traded commodities in the world. ${ }^{1}$ The coffee industry's scope is truly international. ${ }^{2}$ The United States alone consumes twenty percent of the world's coffee, followed by developed areas such as Japan and the European Union (EU). ${ }^{3}$ However, producing, roasting, and processing the coffee bean involves many other countries, including various developing nations and approximately twenty-five million small coffee growers. ${ }^{4}$ Furthermore, some of these developing countries in the global South depend significantly on coffee production as a core of their export earnings, making the coffee market particularly relevant. ${ }^{5}$

Coffee has become a staple of American life. Coffee rose to popularity in the United States throughout the eighteenth century partly as a backlash against the British Empire, a colonial power with a particular preference for tea. ${ }^{6}$ Coffee in the United States may have started as a

* J.D. Candidate, May 2011, Indiana University School of Law - Indianapolis; B.A., 2008, The American University. The author would like to thank the staff of the Indiana International and Comparative Law Review, both past and present, for all of its hard work in helping to publish this Note.

1. See Mark Pendergrast, Coffee Second Only to Oil? Is Coffee Really the Second Largest Commodity, TEA \& COFFEE TRADE J. (2009), available at http://www.entrepreneur.com/ tradejournals/article/198849799_1.html. Determining what rank coffee holds as a traded commodity is complicated by the fact that there are multiple questions to ask in order to rank commodities. Id. Some sources state that coffee is the second most traded commodity in the world behind oil, but Pendergrast indicates that the figures are more nuanced. $I d$.

2. See Seth W. Shannon, Note, Economic Stimulation: The History and Hope of Coffee in Development, 18 Transnat'L L. \& ConTEMP. Probs. 169, 170 (2009).

3. Id.

4. Ezra Fieser, Fair Trade: What Price for Good Coffee?, Time, Oct. 5, 2009, available at http://www.time.com/time/magazine/article/0,9171,1926007-1,00.html.

5. See INT'L COFFEE ORG., International Coffee Agreement 2007: Benefits of Membership 1 (2007), available at http://dev.ico.org/documents/benefits07e.pdf [hereinafter International Coffee].

6. See Mark Pendergrast, UnCommon Grounds: The History of Coffee and How It TRANSFORMEd OUR WORLD 15 (1999) [hereinafter PENDERGRAST, UnCOMMON GROUNDS]. 
political protest beverage, but the bitter brew dripped through various stages of popularity, decline, and quality variation throughout U.S. history. Coffee originated as a drink of low quality commonly consumed by members of the American working class for an extended period of U.S. history. ${ }^{7}$ However, coffee today is of much greater quality due to the rise of specialty coffees and exotic beans. ${ }^{8}$ Coffee is now considered a luxury item by some, a phenomenon due to the high quality of coffee varieties offered as well as the percolation of "café culture" onto the American scene from established, celebrated coffee practices originating in Europe. 9 The modern success of coffee as a beverage consumed in vast quantities by the cultural "crema" has been bolstered in large part from innovations by corporations such as Starbucks, which founded its business on the idea that coffee is a cultural experience. $^{10}$

The modern attitude of coffee-consuming nations, which view coffee and café culture as a relaxing forum for conversation and intellectualism, is in tension with the more negative experience of many coffee-producing nations. These countries, and especially the farmers cultivating coffee crops there, have historically been exploited in order to benefit coffeeconsuming nations. ${ }^{11}$ Past trade deals between coffee purchasers and coffee producers were fraught with inequitable practices that tended to maintain a system of unequal bargaining power on a macroeconomic, global scale. ${ }^{12}$ In response to these unfair practices, the fair trade movement - the system of producer certification, equitable pay, and reinvestment in farming communities - began brewing throughout the coffee industry.

Fair trade coffee has been a particularly fascinating example of an effective and positive fair trade system; ${ }^{13}$ however, it also has drawbacks. ${ }^{14}$ The sustainability of the fair trade coffee movement has been questioned by some who wonder whether the movement's growth potential has peaked. ${ }^{15}$ An examination of the history of fair trade coffee, what current fair trade coffee practices are, and how that system can be sustained into the future is imperative to gauge the continued success of the fair trade coffee movement. The continued viability of the fair trade coffee movement impacts actors on both a global and individual scale, from national economies to small-scale coffee farmers.

7. See id. at 291-94.

8. See id. at 293-94.

9. See William Roseberry, The Rise of Yuppie Coffees and the Reimagination of Class in the United States, in FOOD IN THE USA 149, 154-55 (Carole M. Counihan ed., 2002).

10. See PENDERGRAST, UnCOMMON GROUNDS, supra note 6, at 375.

11. See infra Part II.

12. See Gavin Fridell, fair Trade Coffee: The Prospects and Pitfalls of MARKET-DRIVEN SOCIAL JUSTICE 31 (2007).

13. See infra Part II.B.

14. See infra Parts II.B, III.C.

15. See infra Part II.B. 
Beginning in Part II, this Note examines the origins of fair trade coffee, the effect of international labeling organizations, and fair trade coffee's impact on those who produce the good. The first step in evaluating fair trade is to define fair trade since it has taken on various meanings throughout its history. Part II also explains some of the rationales for fair trade and why it is or is not effective in meeting its proffered goals.

Parts III and IV of this Note explore how the United States approaches fair trade coffee both in a policy context and in a consumer context and contrasts the U.S. approach with the European Union's approach to fair trade coffee. Parts III and IV examine legislative documents of the United States and European Union: United States House Resolution $349^{16}$ and the European Parliament Resolution on Fair Trade and Development, ${ }^{17}$ respectively. Part V details the local government "fair trade town"18 phenomena seen across Europe, especially in the United Kingdom, ${ }^{19}$ and, in a much more limited fashion, the United States. ${ }^{20}$

Recommendations for the sustainability of fair trade based on the above information are offered in Part VI of this Note. First, the United States should, like the EU, show a commitment to the fair trade movement by making this a higher domestic priority and emulating the detailed and comprehensive resolution produced by the European Parliament. ${ }^{21}$ A subgoal in this proposed domestic policy should also be a concentrated effort on the part of the United States to promote a unified labeling approach in the sale of fair trade coffee. Second, local governments should increase consumer awareness of fair trade coffee and encourage the fair trade town initiative.

The conclusion of this Note focuses, perhaps most importantly, on those whose lives are affected positively by fair trade coffee practices. The fundamental reason to encourage and support fair trade coffee is that the practice ultimately benefits those in developing nations who rely on coffee production for their livelihood. ${ }^{22}$

16. See H.R. Res. 349, 108th Cong. (2003).

17. See European Parliament Resolution on Fair Trade and Development, EUR. PARL. Doc. P6_TA (320) (2006), available at $\mathrm{http} / / \mathrm{www}$.europarl.europa.eu/sides/getDoc.do?type $=$ TA\&language $=E N \&$ reference $=$ P6-TA-2006-0320.

18. See infra Part V.

19. See Emma Allen, Turning Towns on to Fairtrade, GUARDIAN, $\mathrm{http} / /$ www.guardian.co.uk/starbucks-fairtrade/fairtrade-community-garstang (last visited Dec. 19, 2010).

20. See Kara DiCamillo, America's Only Fair Trade Town: Media, PA, TReEHugger (Jan. 19, 2007), http://www.treehugger.com/files/2007/01/americas_only_f.php.

21. See infra Part IV.

22. See International Coffee, supra note 5, at 1. 


\section{HISTORY OF FAIR TRADE COFFEE}

As a concept, fair trade encompasses a multitude of agricultural goods traded around the world and seeks to put agricultural goods producers on par with agricultural goods purchasers. ${ }^{23}$ Fair trade is a response to international market forces that have traditionally disadvantaged workers in the agricultural field, particularly in poorer, developing nations. ${ }^{24}$

[Fair trade] contributes to sustainable development by offering better trading conditions to, and securing the rights of, marginalized producers and workers - especially in the South. Fair Trade Organizations, backed by consumers, are engaged actively in supporting producers, awareness raising and in campaigning for changes in the rules and practice of conventional international trade. ${ }^{25}$

Shared principles for all areas of fair trade include increased market access for producers, increased equitable trading relationships, increased producer knowledge- and skill-building, and increased consumer awareness. ${ }^{26}$

In the specific context of coffee production, fair trade maintains these universal principles while gearing its initiatives toward the unique challenges faced by coffee growers and coffee producers. ${ }^{27}$ For example, fair trade coffee practices strive to ensure that purchasers pay a price equal to or above coffee market prices to producers ${ }^{28}$ who were historically exploited by unscrupulous middlemen. ${ }^{29}$ Additionally, fair trade coffee organizations encourage increased investment in local coffee production. ${ }^{30}$ This is achieved by farmers who reinvest a portion of their earnings into education efforts and other sustainable community-building programs, often through organized and democratically-run cooperatives. ${ }^{31}$ Farmers engaging in fair trade are also required to respect the environment by using environmentally sustainable growing practices. ${ }^{32}$ In the absence of a fair

23. See World Fair Trade Org. and Fairtrade Labelling Orgs. Int'l, A Charter OF FAIR TRADE PRINCIPLES 5 (2009), available at http://www.european-fair-tradeassociation.org/observatory/images/stories/file/Charter\%20of\%20Fair\%20Trade\%20principl es\%20-en.pdf.

24. See id. at 3.

25. Id. at 4.

26. See id. at 5 .

27. See Fairtrade in General, FAIRTRADE FouND., http://www.fairtrade.org.uk/what_is fairtrade/faqs.aspx (last visited Jan. 9, 2011).

28. See id.

29. See Jill Draeger, Note, Perking Up the Coffee Industry Through Fair Trade, 11 MinN. J. Global TRade 337, 356 (2002).

30. See id. at 337.

31. Id.

32. See id. at 351-52. 
trade structure, coffee farmers end up selling their goods on international markets at the mercy of market fluctuations and middlemen who exploit less knowledgeable farmers. ${ }^{33}$

Ensuring that purchasers pay producers a price equal to or above coffee market prices is difficult because several factors are used to determine coffee's "fair" price. A coffee farmer harvests beans off the coffee plant first in the form of a "cherry," whose flesh is removed to obtain the actual coffee bean. ${ }^{34}$ The process for removing the cherry shell involves drying the shell and bean either naturally or with the help of mechanical dryers. ${ }^{35}$ The farmer may choose to sell the coffee bean in its cherry shell, but the market price is given for the beans alone. ${ }^{36}$ It is important to specify the point and condition at which the coffee beans are sold because the fair price determination depends on the process that farmer has undertaken to prepare the crop. ${ }^{37}$ Further, the fair trade certification applies to "growers;" however, this could refer to the entity owning the land on which the coffee crop is grown or the individual farmer, which may or may not be the same person. ${ }^{38}$ Determining the actual fair trade grower is an important inquiry in determining who receives the major share of the price paid and what percentage of that payment the coffee farmer receives.

\section{A. Fair Trade Brewing: Max Havelaar}

Fair trade in general began in the mid-twentieth century, ${ }^{39}$ but the fair trade coffee movement began with the idea of a labeling scheme in the $1980 \mathrm{~s}^{40}$ Labeling goods signaled to consumers which commodities met certain quality criteria and, perhaps more importantly, disseminated the fair trade idea to markets. ${ }^{41}$ The first fair trade coffee label, Max Havelaar, was launched in 1988, "under the initiative of the Dutch development agency Solidaridad. The first 'Fairtrade' coffee from Mexico was sold in Dutch supermarkets and was branded 'Max Havelaar,' after a fictional Dutch character who opposed the exploitation of coffee pickers in Dutch colonies. ${ }^{, 42}$

33. See Shannon, supra note 2, at 178-79.

34. See Jill Richardson, Does Fair Trade Coffee Lift Growers Out of Poverty or Simply Ease Our Guilty Conscience?, ALTERNET (Feb. 11, 2010), http://www.alternet.org/ story/145555/.

35. See id.

36. Id.

37. Id.

38. Id.

39. See Fairtrade - History, FAIRTRADE FouND., http://www.fairtrade.org.uk/what_is fairtrade/history.aspx (last visited Jan. 9, 2011).

40. See id.

41. Id.

42. Id. 
The Max Havelaar idea spawned similar initiatives in many other countries, many of which developed their own separate labeling schemes. Throughout the late 1980s and the early 1990s, the Max Havelaar label expanded to Belgium, Switzerland, Denmark, Norway, and France. ${ }^{43}$ The label "TransFair" was developed for Germany, Austria, Luxemburg, Italy, the United States, Canada, and Japan, while the "Fairtrade Mark" was developed for the UK and Ireland. ${ }^{44}$

\section{B. Modern Fair Trade Labeling Organizations}

The primary objective of the various modern labeling organizations is certification of the commodities they oversee. ${ }^{45}$ The regime currently in place to enforce the established international standards for fair trade coffee certification is a network of non-governmental organizations (NGOs) working in concert under a central coordinating organization. ${ }^{46}$ This umbrella network is called the Fairtrade Labelling Organizations International (FLO), which was established in 1997 as a way to unify fair trade practices. ${ }^{47}$ FLO uses the trademarked term "Fairtrade" to refer to itself and its standards for certification; however, this is distinct from the concept of "fair trade," which refers to the fair trade movement and economic concept generally. ${ }^{48}$

FLO works to meet three objectives. ${ }^{49}$ First, it certifies fair trade licensees, a process that includes certification training and developing materials for inspection. ${ }^{50}$ Second, FLO "facilitates business contacts between licensed fair trade producers and traders." ${ }^{\text {"51 }}$ Third, the organization promotes business and technical support for associated workers and producers. ${ }^{52}$ FLO has seen success since its inception, as sales of its certified goods have risen thirty-five percent from 1997 to $2000 .^{53}$

The global labeling scheme is complicated by the fact that labeling exists not only for certified fair trade practices, but also for other sustainable initiatives along the same lines as fair trade, such as organic

43. See id.

44. Id.

45. See Scott B. Weese, Note, International Coffee Regulation: A Comparison of the International Coffee Organization and the Fair Trade Coffee Regimes, 7 CARDOZO PUB. L. POL'Y \& ETHICS J. 275, 294 (2008).

46. See id. at 295.

47. See Fairtrade - History, supra note 39.

48. See Frequently Asked Questions, FaIRTRADE LABELling ORGS. INT'L, http://www.fairtrade.net/faqs.html (last visited Jan. 9, 2011).

49. See FrIDELL, supra note 12, at 55.

50. See id.

51. Id.

52. See id.

53. Id. at 58 . 
coffees, shade-grown coffees, etc. ${ }^{54}$ The global unified labeling scheme is further frustrated by the fact that while FLO is the international face of modern fair trade coffee certification, each country has its own domestic initiative that works in conjunction with FLO and is responsible for disseminating the licensed label for fair trade certified coffees sold in its own country. ${ }^{55}$ For example, TransFair USA is the organization responsible for fair trade coffee certified by FLO in the United States. ${ }^{56}$ TransFair USA, FLO, and other associated labeling organizations work together to label commodities consistently, ${ }^{57}$ but despite efforts to create unified labels, organizations sometimes use distinct labels. ${ }^{58}$

Statistically, the work undertaken by FLO and its associated labeling organizations is significant. For example, the value of the amount of Fairtrade certified coffee sold in the United Kingdom in 2008 was $£ 137.3$ million (\$224.5 million USD). ${ }^{59}$ In contrast, the value of the amount of Fairtrade certified coffee sold in the United Kingdom in 1998 was only $£ 13.7$ million (\$23 million USD). ${ }^{60}$ In 2008 TransFair USA imported $87,772,966$ pounds of fair trade certified coffee into the United States, compared to only 76,059 pounds in $1998 .^{61}$ FLO estimates that sales of its products have grown an average of forty percent in the last five years. ${ }^{62}$ In 2009 worldwide sales of Fairtrade products were approximately $€ 2.9$ billion (\$4.34 billion USD), a twenty-two percent year-to-year increase. ${ }^{63}$ Interestingly, Switzerland has consumed the largest amount of FLO-labeled goods from 1997 to 2000 , while the United States only represents 0.2 percent of total FLO-labeled goods over the same period. ${ }^{64}$

Although growth of the fair trade market has boomed in recent decades, there are indications that fair trade coffee practices have limitations in the market and, moreover, that expansion of fair trade coffee practices may be slowing. Some estimate that coffee cooperatives in the global South can only sell twenty percent of their coffee beans certified by

54. See Grace H. Brown, Note, Making Coffee Good to the Last Drop: Laying the Foundation for Sustainability in the International Coffee Trade, 16 GEo. INT'L ENVTL. L. REV. 247, 262 (2004).

55. See Weese, supra note 45 , at 295.

56. See Fieser, supra note 4.

57. See Fairtrade in General, supra note 27.

58. Id.

59. Fairtrade - Facts and Figures, FAIRTRADE FOUND., http://www.fairtrade.org.uk/ what_is_fairtrade/facts_and_figures.aspx (last visited Dec. 19, 2010).

60. Id.

61. TRANSFAIR USA, ALMANAC: 20081 (2008), available at http://transfairusa.org/ pdfs/almanac_2008.pdf.

62. Facts and Figures, FAIRTRADE LABELLING ORGS. INT'L, http://www.fairtrade.net/ facts_and_figures.html (last visited Dec. 19, 2010).

6j. $I \bar{d}$.

64. See FRIDELL, supra note 12, at 59 . 
FLO on fair trade markets, with the rest sold on traditional markets. ${ }^{65}$ Furthermore, there are signs that a glass ceiling has been reached in some consumer countries where fair trade commodities have been on sale for decades. $^{66}$ For instance, while fair trade sales growth in countries like Italy, France, and Belgium was healthy in the mid-1990s, growth in places where fair trade coffee has been long established, like the Netherlands, Switzerland, Germany, and the UK, was sluggish or nonexistent. ${ }^{67}$

\section{CuRRENT U.S. FAIR TRADE CofFEe PoliCy}

\section{A. International Coffee Agreements and the "Coffee Crisis"}

The United States policy pertaining to fair trade coffee is both domestic and international. In the context of international economic involvement, U.S. coffee policy has spanned the political spectrum, from active governmental engagement to free market principles.

The starting point for the United States' involvement in the global coffee trade is the International Coffee Agreement (ICA), a trade agreement formed in the $1960 \mathrm{~s}$ as a response to the unstable financial environment from which coffee commodities suffered. ${ }^{68}$ The ICA was one of the earliest reactions to the economic hardships resulting from market price fluctuations faced by many coffee-producing farmers. ${ }^{69}$ The original ICA contemplated several economic goals, most of which were focused on price stability, amelioration of coffee farmer hardships, and increased coffee consumption. $^{70}$ Although initially hesitant to join the ICA for fear that it would unduly interfere with international free trade, the United States joined in 1962."1 A likely reason for U.S. participation in the agreement was the desire to protect economic interests in areas where coffee was produced: for example, Latin American countries thought to be susceptible to a political shift toward communism in the event of economic collapse. ${ }^{72}$ Later International Coffee Agreements were subsequently signed in 1968, 1976 , and $1983 .^{73}$

During its implementation on the world economic stage, the ICA seemed to have been successful in preventing severe poverty in coffeeproducing nations, as it was able to prohibit a dangerously low fall in

65. See id. at 64 .

66. See id.

67. See id. at 64-65.

68. See Brown, supra note 54, at 250-51.

69. See Shannon, supra note 2, at 174.

70. See id.

71. See Brown, supra note 54, at 250-51.

72. See id. at 251.

73. See Draeger, supra note 29 , at 344. 
prices. ${ }^{74}$ Ultimately, however, one of the major drawbacks of the ICA was its inability to realize its long-term goal of coffee price stabilization despite the use of quota restrictions on exporting countries intended to regulate supply and price. ${ }^{75}$ The strong regulatory ICA that existed at its inception and throughout the 1970s and 1980s ultimately expired in $1989 .^{76}$

Reasons for the ICA's demise are two-fold. ${ }^{77}$ First, the United States withdrew its support because the threat of communism in Latin America diminished $^{78}$ and because the United States shifted its economic ideology toward free trade policies. ${ }^{79}$ Second, the ICA's regulations no longer fit the global economic climate as coffee-producing countries outgrew the fixed quota system while penalties for noncompliance were lessened. ${ }^{80}$ The significance of the ICA was greatly diminished with the withdrawal of the United States as a signatory and a nation with great economic weight. ${ }^{81}$

After the ICA's demise, the coffee market saw a period of harmful coffee crop surplus, which was eventually followed by the "coffee crisis." The international coffee crisis, still present in the global market today, is a severe disequilibrium between the demand for coffee beans and its supply. ${ }^{83}$ The oversupply of coffee, along with a decrease in the overall price for the commodity, has resulted in both harmful economic implications for coffee prodúcers and environmental and health concerns, such as using children to work in fields, switching to the cultivation of illicit crops like opium, or using harsh chemicals. ${ }^{84}$

Three overall factors collided to create the global coffee crisis. The central reason for the economic crisis was the breakdown of a strong, regulatory ICA ${ }^{85}$ When the ICA regulated coffee prices for coffee from the 1960 s to the late 1980 s, coffee producers enjoyed relative price predictability and stability through an enforced price "corset" that held the commodity price within a certain range. ${ }^{86}$ Furthermore, participating countries agreed not to oversupply the marketplace, thereby maintaining a

74. See Brown, supra note 54, at 251.

75. See id.

76. See Shannon, supra note 2, at 176-77.

77. See id.; Draeger, supra note 29 , at 345.

78. See Shannon, supra note 2, at 177.

79. See Draeger, supra note 29 , at 345.

80. See id.

81. The ICA still exists, but its objectives are more focused now on awareness, education, and promotion, which significantly decrease the impact of its regulatory powers. Id. at 181 .

82. Brown, supra note 54 , at 252.

83. See Seth Petchers \& Shayna Harris, The Roots of the Coffee Crisis, in Confronting the Coffee Crisis: FaIR TRAde, Sustainable Livelinoods and Ecosystems IN MeXico AND CENTRAL AMERICA 43, 44 (Christopher M. Bacon et al. eds., 2008).

84. See Brown, supra note 54 , at 255-57.

85. See Petchers \& Harris, supra note 83 , at 44.

86. See id. 
stable supply and demand equilibrium. ${ }^{87}$ However, in the regulatory vacuum left by the ICA breakdown in 1989, prices for coffee beans became unpredictable and unstable. ${ }^{88}$

The second factor contributing to the coffee crisis was the changing landscape of the major coffee producers. ${ }^{89}$ In recent decades, Brazil, currently the world's largest coffee-producing country, improved its crop production and developed new methods of increasing crop yields. ${ }^{90}$ This led to increased crop supply and exacerbated the supply/demand imbalance in the world coffee market. ${ }^{91}$ Additionally, in the 1990s, Vietnam became the second largest producer of coffee in the world. ${ }^{92}$ Its recent coffee exportation flooded the market with surplus beans, including fifteen million pounds of coffee in $2000 .^{93}$

The third factor in the coffee crisis was a decrease in coffee demand in major coffee-consuming countries. ${ }^{94}$ While coffee production has remained either stable or rising in many parts of the world, recent drops in demand in major coffee-consuming nations have heightened the effects of the weakened ICA and the oversupply by Brazil and Vietnam. ${ }^{95}$ However, the specialty coffee marketplace has not experienced the same drop in demand as more common varieties of coffee. ${ }^{96}$ Although specialty coffee is a hopeful prospect in combating the effects of the coffee crisis, it represents only a small percent of the overall coffee production market. ${ }^{97}$

The fair trade movement has attempted to alleviate some of the harmful effects experienced by coffee producers in the wake of the extended market disequilibrium. ${ }^{98}$ However, even with some form of market regulation, ${ }^{99}$ conditions have never been ideal or equitable for smallscale coffee farmers. If regulatory measures were to come back into play (a helpful policy decision recommended in this Note), the fair trade movement would still have much to contribute to both the maintenance of a more stable economic climate for the coffee market and to the improvement of the living conditions of those involved in the growing, roasting, and exporting of the coffee bean.

87. See id.

88. See Brown, supra note 54, at 252.

89. See Petchers \& Harris, supra note 83 , at $45-46$.

90. See id.

91. See id.

92. See id. at 45-46.

93. See id.

94. Id. at 46.

95. See id. at 45-46; Brown, supra note 54 , at 254.

96. See Brown, supra note 54, at 254.

97. See id.

98. See supra Part II.

99. The ICA provided this type of suggested regulation throughout the last few decades of the twentieth century. See Shannon, supra note 2, at 174. 
To a certain extent, the fair trade concept itself has created economic conundrums. For example, when coffee prices are low, the appeal of fair trade participation, in the form of cooperatives, naturally increases. ${ }^{100}$ However, if demand for fair trade coffee fails to increase along with the resulting increased fair trade coffee supply, purchasers are forced to dump excess fair trade coffee onto conventional markets. ${ }^{101}$ This can potentially drive down the overall price of coffee and perpetuate a cycle that requires farmers to continue participation in a fair trade coffee scheme. ${ }^{102}$ Currently, coffee supply surpluses are not serious because of the relatively small amount of fair trade coffee in the economy. ${ }^{103}$ This theoretical cycle is affected by a plethora of factors, but it may highlight one reason increased demand for fair trade coffee would be generally positive for fair trade certified farmers when they sell their crops.

\section{B. United States House Resolution 349}

While the United States has been quite active in both developing policy for the international coffee market and incorporating coffee in trade agreements, ${ }^{104}$ it has yet to pass any domestic legislation that addresses coffee products or regulation of fair trade coffee. For example, the most substantial legislation pertaining to coffee was House Resolution 349 (H.R. 349), which was promulgated by the 108th Congress in $2003 .^{105}$ H.R. 349, titled "Encouraging the Consumption of Fair Trade Certified Coffee," was introduced by Representative Pete Stark of California ${ }^{106}$ along with seventeen co-sponsors. ${ }^{107}$ The first part of the Resolution includes the House's acknowledgement of the economics of the international coffee trade and how it affects both producers and consumers:

Whereas in the context of the global economy, consumer choices and institutional purchases affect communities and the environment throughout the world; ...

Whereas according to the International Coffee Organization, coffee producing countries are now only earning $\$ 5.5$ billion in revenue from a $\$ 70$ billion global

100. See James McWilliams, Fair Trade and the Food Movement, N.Y. TIMES FREAKONOMICS BLOG (June 30, 2010, 10:30 AM), http://freakonomics.blogs.nytimes.com/ 2010/06/30/fair-trade-and-the-food-movement/.

101. See id.

102. See id.

103. See id.

104. See supra Part III.A.

105. See H.R. Res. 349, 108th Cong. (2003).

106. Id.

107. Id. 
coffee industry, while in 1989 , coffee producing countries earned $\$ 12$ billion in revenue from a $\$ 30$ billion global coffee industry; ...

Whereas Fair Trade Certification is a solution that ensures a minimum price per pound of coffee at $\$ 1.26$ for producers and grants them access to credit; ...

Whereas there is an independent market for Fair Trade Certified coffee, but the overall supply of Fair Trade Certified coffee far exceeds current market demand by at least 130 million pounds... ${ }^{108}$

The Resolution concludes by giving three recommendations. ${ }^{109}$ First, the government has a responsibility to deliver its food support services in the fairest manner possible by requiring a high standard of ethics. ${ }^{110}$ Second, the House would like fair trade coffee at all events and food service locations for the government where possible. ${ }^{11}$ Finally, "information should be made available to the public and to State and local governments about the importance of Fair Trade Certified coffee." 112

Representative Stark, in comments made while introducing the Resolution, indicated that this piece of legislation would promote the sale of fair trade coffee and raise its awareness to the public while not burdening Congress in any significant way. ${ }^{113}$ Representative Stark recognized that the force of the Resolution was more in its symbolic nature and less in actual policy change, being a gesture that sent a signal to the country about the government's commitment to fair trade practices. ${ }^{114}$ Representative Stark saw no reason why the federal government could not serve fair trade coffee in its buildings and at government functions, especially given that major corporations did the same in their stores. ${ }^{115}$ The purpose of the Resolution, for Representative Stark, was both to acknowledge that fair trade coffee can help alleviate the effects of the coffee crisis and to inform the public about the benefits fair trade coffee creates for coffee farmers. ${ }^{116}$ Representative Stark hoped that H.R. 349 would reflect the value of fairness by serving as the first step in an effort to curb the abuses suffered by coffee

108. Id.

109. Id.

110. Id.

111. Id.

112. Id.

113. 149 CONG. REC. 19,878 (2003) (statement of Rep. Stark).

114. See id. at 19,879 .

115. See id.

116. See id. 
producers at the hands of middlemen. ${ }^{117}$ The Resolution, while symbolic in nature, should not be ignored because there is value in voicing support for fair trade coffee practices and raising awareness of the fair trade movement. However, the sponsors of H.R. 349 realize that resolutions promulgated by the U.S. House and Senate do not have the force of law and therefore have an inherently limited impact. ${ }^{118}$

As Representative Stark acknowledged, this Resolution is not a significant burden on the federal government. ${ }^{119}$ It is unclear whether actual legislation, as opposed to just another resolution that provided for fair trade coffee in federal food service venues, would be a burden on the government to implement. Further, legislation mandating that the government serve fair trade coffee would likely send an even stronger message to the public in support of fair trade coffee practices. Unfortunately, only H.R. 349 and another resolution generally recognizing the coffee crisis is the only attention the federal legislative branch has given to the possibility of implementing fair trade coffee practices. ${ }^{120}$

\section{Starbucks: The Impact of Corporations}

Although international political economy and governmental responses are partial aspects to a complicated economic situation created by the international coffee trade, private commercial enterprises are hard to ignore in any meaningful economic analysis. Coffee leviathan Starbucks has led the way in the private sector's involvement in fair trade coffee. In 2005 Starbucks paid an average of twenty-three percent higher than average market price for its coffee, a price that exceeded the fair trade minimum price. $^{121}$ Starbucks's purchases of fair trade certified coffee show an impressive upward trend. ${ }^{122}$ Starbucks purchased 4.8 million pounds of fair trade coffee in $2004,11.5$ million pounds in $2005,{ }^{123}$ and pledged to purchase 40 million pounds in $2009 .{ }^{124}$ Recently, Starbucks announced

117. See Fair Trade Coffee Resolution Introduced in the House of Representatives, JusTFoOD.COM (July 19, 2002), http://www.just-food.com/article.aspx?id=69746.

118. See Legislation, Laws, and Acts, U.S. SENATE, http://www.senate.gov/legislative/ common/briefing/leg_laws_acts.htm (last visited Dec. 19, 2010).

119. See 149 CONG. REC. 19,878 .

120. See H.R. Res. 349, 108th Cong. (2003); H.R. Res. 604, 107th Cong. (2002); S. Res. 368, 107th Cong. (2002) (mirroring the House Resolution).

121. Alison Benjamin, Fair Dunk'em, Guardian, (Feb. 9, 2006, 15:30 GMT), http://www.guardian.co.uk/environment/2006/feb/09/food.fairtrade.

122. See id.

123. Id. Also, in 2004 Starbucks created its own farmer equity scheme called Shared Planet because small-holder farms certified by other international groups represented only two percent of the world's coffee supply. Id.

124. Starbucks Says It Will Double Its Buying of 'Fair-Trade' Coffee, Bus. REV. (Albany), Oct. 29, 2008, available at http://albany.bizjournals.com/albany/ stories/2008/10/27/daily $28 . \mathrm{html}$. 
that, in a partnership with FLO, all of the company's espresso-based drinks, such as lattes and cappuccinos, would be made with Fairtrade-certified espresso by March 2010. ${ }^{125}$ Additionally, Starbucks features its fair trade Café Estima blend coffee in over 10,000 of its stores in more than fifty-five countries. $^{26}$ At least one positive aspect of Starbucks's involvement in fair trade coffee is its ability to expose consumers to fair trade coffee purchasing options primarily due to the pervasive nature of Starbucks' global brand.

The participation of Starbucks in the fair trade coffee movement potentially changes the focus and direction of the movement. As political scientist Gavin Fridell notes, involvement of major corporations in fair trade transforms the movement from one of concerted efforts by various small advocacy groups to a movement driven by the interests of corporations as they pursue a niche market. ${ }^{127}$ Some argue that pursuing fair trade coffee in order to reach out to a niche market may be problematic because it represents an inadequate commitment to fair trade coffee. ${ }^{128}$ Another problem Fridell points out is that the increased participation of major corporations like Starbucks in fair trade perpetuates some of the limitations the fair trade network experiences in a market-based model. ${ }^{129}$ Further, Fridell argues that corporate-driven expansion of the fair trade coffee movement receives its motivation not from a genuine concern about producers or consumers, but from a desire to protect the corporation's public image and its profitability. ${ }^{130}$

However, from a market-based perspective it is ultimately advantageous to have a major player like Starbucks participating in the fair trade coffee scheme if only because of the sheer volume of resources available to the retailer to boost fair trade coffee purchases and sales. Because Starbucks is the largest purchaser of fair trade certified coffee in the world, ${ }^{131}$ the end result of its massive purchasing volume is that more coffee producers benefit from fair trade. Even some working in the fair trade movement recognize that the financial weight of business entities represents a potential source of growth for the movement. ${ }^{132}$ In fact,

125. See $100 \%$ of Starbucks Espresso in Europe to be Starbucks Shared Planet and Fairtrade Certified, STARBUCKS (Sept. 10, 2009), http://news.starbucks.com/article_display. cfm?article_id=265.

126. Brigid Darragh, Starbucks Featuring Fair Trade Coffee in 10,000 Stores, GreEN CHIP STOCKS (Apr. 21, 2010), http://www.greenchipstocks.com/articles/starbucks-new-fairtrade/916.

127. See FRIDELL, supra note 12, at 6 .

128. See id. For example, Starbucks has only certified as fair trade six percent of its coffee beans. Id.

129. See id.

130. See id. at 73.

131. See Fieser, supra note 4.

132. See Peter Gaynor, Aid and Trade in Developing World, IRISH TIMEs, July 26, 2010, available at http://www.irishtimes.com/newspaper/letters/2010/0726/1224275466859.html. 
businesses might be able to have the largest impact of the volume of fair trade coffee purchased. ${ }^{133}$ Part of the overall success of the fair trade movement may come from corporate involvement; ${ }^{134}$ therefore, this participation should be encouraged.

\section{CURRENT EU FaIR TRADE COFFEe POlicy: THE SChMidT REPORT}

The European Parliament, the EU's only directly elected body, ${ }^{135}$ passed the Resolution on Fair Trade and Development in 2006. ${ }^{136}$ The Parliament's Committee on Development promulgated the Resolution. The Resolution, nicknamed the "Schmidt Report" after its author and committee member Frithjof Schmidt (hereinafter referred to as either the Resolution or the Report), was based on an earlier report on fair trade coffee compiled Mr. Schmidt. ${ }^{137}$

\section{A. Preamble}

The Resolution is of considerable length and detail. ${ }^{138}$ It begins by recognizing the impact fair trade can have on socially conscious practices: "Fair Trade and other independently monitored trading initiatives contributing to raising social and environmental standards have in common their ambition to market, sell and promote trade in products which comply with certain social, environmental and development criteria."139

As the Schmidt Report acknowledges, "Fair Trade pursues two inseparable objectives" by providing "opportunities for development for small-scale producers" as well as prompting "the international trading system ... to operate in a way which is fairer and more conducive to sustainable development."140 This passage exemplifies the high level of understanding the Resolution's authors have for fair trade and its potential to further policy objectives. In addition to government action, the Resolution also recognizes the role of citizens in the fair trade network

133. See id.

134. See FrIDELL, supra note 12, at 53. Fridell does not argue that this scheme is ideal; on the contrary, he argues that a market-based approach may not be the most effective route to fair trade policies while recognizing that the fair trade movement has benefitted from neoliberal market policies. Id.

135. See Welcome to the European Parliament, EUROPEAN PARLIAMENT, http://www.europarl.europa.eu/parliament/public/staticDisplay.do?language=EN\&id=146 (last visited Dec. 19, 2010).

136. European Parliament Resolution on Fair Trade and Development, supra note 17.

137. See id.

138. See id.

139. Id. I B. The Resolution also acknowledges fair trade's potential for raising social standards and for eradicating poverty, something the EU has sought to do in its Millennium Development Goals. Id. ๆ C.

140. Id. ๆ $\mathrm{G}$. 
through ideas such as public campaigns and other cooperative efforts. ${ }^{141}$ The Resolution also specifically mentions the phenomenon of fair trade towns as a way to raise awareness about choosing fair trade products. ${ }^{142}$ Connected to the role of consumers in fair trade, the Schmidt Report addresses the importance of retailers in the fair trade system in promoting fair trade practices: "[A]n increasing number of European retailers make significant efforts to support Fair Trade and other independently monitored trading initiatives contributing to raising social and environmental standards by communicating their values and offering their products in their outlets...."143

Another important preamble statement focuses on the lack of legal protection for general fair trade practices and the fear that companies may, in light of the success of the fair trade movement, exploit the positive reputation of fair trade products without complying with the required fair trade criteria. ${ }^{144}$ This is a wise consideration given that fair trade is growing internationally. ${ }^{145}$ This acknowledgement also bolsters an argument for a uniform labeling initiative, which would help eliminate abusive practices of companies using false, misleading, or meaningless labels. ${ }^{146}$ The potential for abuse should be especially recognized in areas where fair trade practices are growing today, like the United States, in order to maintain the integrity of fair trade products. ${ }^{147}$

\section{B. Substantive Provisions}

The substantive portion of the Schmidt Report contains many relatively specific recommendations that European governments at various levels can heed in order to promote fair trade practices, increase fair trade awareness, and support the success of the fair trade movement generally.

One of the first of the Resolution's thirty-three recommendations combats the problem of potential abuse of the fair trade system by exploitive companies. ${ }^{148}$ This recommendation calls for the regulation of overall fair trade practices by using specific criteria that would streamline the fair trade certification process, ensure quality in fair trade products, and,

141. See id. $\| \mathrm{I}$; infra Part V.

142. See European Parliament Resolution on Fair Trade and Development, supra note 17, II I.; infra Part V.

143. European Parliament Resolution on Fair Trade and Development, supra note 17, II K.

144. See id. ๆ S.

145. See supra Part II.B.

146. See infra Part VI.A.2.

147. See supra Part II.B.

148. See European Parliament Resolution on Fair Trade and Development, supra note 17, If $\mathrm{S}$. 
most importantly, guarantee fairness to fair trade producers. ${ }^{149}$

The Report also emphasizes that a central source of strength for the overall fair trade movement has been its labeling initiative, which serves as both a signal to consumers and a quality assurance device. ${ }^{150}$ The Report, reinforcing the importance of having a singular and powerful labeling scheme among labeling organizations that indicates fair trade principles and fair trade quality, "[s]tresses that the most significant part of the increase in Fair Trade sales has been achieved with respect to labelled products."151 The Resolution goes on to make more pointed efforts at initiating action. ${ }^{152}$ The Committee adopting the Resolution "[c]alls on the Commission to launch specific calls for proposals in relation to Fair Trade targeted at raising consumer awareness, supporting assurance schemes and labelling and systematic data collection and assessment of effects across the EU...."153 This admonishment to action demonstrates a certain level of seriousness of the European Parliament both to EU member states and to the international trade community about enacting the recommended proposals and providing for the growth of ideas like consumer awareness and labeling schemes. ${ }^{154}$

The twenty-fourth recommendation in the Resolution encourages the European Parliament to offer fair trade products and further recommends that all EU-related bodies serve fair trade goods. ${ }^{155}$ This is essentially the entirety of the substance of the U.S. counterpart to the Schmidt Report, U.S. House Resolution 349. ${ }^{156}$

As with most legislative resolutions, the Schmidt Report does not legally bind the European Parliament. ${ }^{157}$ However, it serves as a clear guideline for how various levels of European government can actively promote fair trade practices. The Resolution is impressively detailed and thorough, which places it in stark contrast from other, more superficial

149. See id. $\| 2$.

150. See id. ๆN.

151. Id. \3.

152. Id. II 13.

153. European Parliament Resolution on Fair Trade and Development, supra note 17, 11 13. The "Commission" referred to is the European Commission, the executive-type branch of the European Union, which proposes legislation, participates in the decision-making process, carries out various policies, treaties, and etc. See The European Commission at Work - Basic Facts, EUROPEAN COMM'N, http://ec.europa.eu/atwork/basicfacts/ index_en.htm (last visited Dec. 19, 2010).

154. See generally European Parliament Resolution on Fair Trade and Development, supra note 17 (displaying a thorough consideration of research about and proposals for fair trade coffee sustainability).

155. See id. ๆ 24.

156. See H.R. Res. 349, 108th Cong. (2003); supra Part III.B.

157. See European Parliament Resolution on Fair Trade and Development, supra note 17, I1. 
resolutions like H.R. 349. ${ }^{158}$ The Schmidt Report raises many important points about how to positively benefit the global fair trade scheme by sustaining fair trade in the future.

\section{Report Comments}

The Schmidt Report ${ }^{159}$ is accompanied by an explanatory statement detailing some of the reasons for the Resolution's adoption. The statement lists five primary reasons to develop a policy for fair trade in the EU which echo many of the sentiments the actual Resolution lists in its Preamble. ${ }^{160}$ The first purpose for generating a fair trade policy framework is to promote the EU's goal of encouraging sustainable development and poverty reduction. ${ }^{161}$ This goal is squarely aligned with the general principles promoted by the fair trade movement and seemingly represents a recognition on the part of the European Parliament that its social policy goals are in accord with and can, to a certain extent, be implemented through fair trade practices. ${ }^{162}$

The second reason to develop fair trade policy is that the EU has entered into legally binding treaties that advocate support for fair trade, such as the Cotonou Agreement. ${ }^{163}$ However, the Report notes that the support given to fair trade practices in the EU and to the various coordinating organizations is "limited and fragmented," "which seems to be an attempt to give recommendations in support of a unified policy on fair trade practices.

The Report states that the third reason for promulgating the Resolution is a desire to harness the growth potential of the fair trade movement in an effort to increase consumer awareness and fair trade demand. $^{165}$ The Report recognizes that the EU represents a significant percentage of sales of fair trade goods globally and that its growth in countries where fair trade goods are less established will be significant in the future. Thus, the campaign to increase consumer awareness will have a direct impact on fair trade demand in countries where the fair trade movement is not established. ${ }^{166}$

158. See supra Part III.B.

159. See Report on Fair Trade and Development, EUR. PARL. DOC. A6-0207 1 (2006), available at http://www.europarl.europa.eu/sides/getDoc.do?pubRef $=-/ / \mathrm{EP} / \mathrm{NONSGML}+$ REPORT+A6-2006-0207+0+DOC+PDF+V0//EN.

160. See id.; European Parliament Resolution on Fair Trade and Development, supra note 17.

161. See Report on Fair Trade and Development, supra note 159, at 11.

162. See supra Part II.

163. See Cotonou Agreement, 2000 O.J. (L 317) 3; supra Part II.

164. Report on Fair Trade and Development, supra note 159, at 11.

165. See id.

166. See id.; supra Part II.B. 
The fourth reason for promulgating the Resolution is related to the phenomenon of fair trade growth among EU member states. ${ }^{167}$ The Report explains that as fair trade practices expand throughout the EU, national legislation regulating the trade will likely be passed. ${ }^{168}$ A supranational, EU-based framework of regulation will avoid legislative differences of EU member governments and therefore avoid a hindrance of the "free movement of goods within the European Union." 169

The fifth and final reason the Report gives to adopt the European Parliament Resolution is to protect consumers of fair trade products. ${ }^{170}$ This final reason echoes statements in the actual Resolution concerned with the potential for labeling abuse by noncompliant companies. ${ }^{171}$ The Report explains that the standards for fair trade practices have been promulgated with great care and that these promulgated practices adhere to strict guidelines in order to maintain a high level of quality assurance for their certified products in order to protect the consumer from potential systematic abuses. $^{172}$

\section{FAIR TRADE TOWNS}

Both national governments and multinational corporations play a significant role in the international coffee trade by influencing the implementation and promotion of fair trade coffee practices. ${ }^{173}$ However, an increasing trend among grassroots organizations and local governments provides a new and promising approach to fair trade. One of the most important aspects of fair trade's effectiveness is the demand it creates among consumers for fair trade products. The rise of cities declaring themselves "fair trade towns" serves to raise consumer awareness about the benefits of fair trade coffee at a community level. ${ }^{174}$

The ideological underpinnings of fair trade towns are rooted in the concept of "ethical consumerism." At first blush, this may sound like an oxymoron because, while being ethical brings to mind notions of fairness

167. See Report on Fair Trade and Development, supra note 159, at 12.

168. Id.

169. Id. Fair trade practices regulated by individual states independently may present roadblocks to successful expansion. This is an important consideration not only for the EU, but also for states the world over that participate in some way in the fair trade scheme; the idea of supranational governance raises significant question about what level of government would be most effective in developing fair trade policy. See supra Parts II.B, III.A.

170. See Report on Fair Trade and Development, supra note 159, at 12.

171. See European Parliament Resolution on Fair Trade and Development, supra note 17, I $\mathrm{S}$.

172. See Report on Fair Trade and Development, supra note 159, at 12.

173. See generally supra Part III (detailing international trade agreements and corporate involvement in the fair trade coffee market).

174. See supra Parts III.A-B. 
and doing right, consumerism is more aimed at individualistic purchasing without regard to consequences. ${ }^{175}$ At its core, ethical consumerism is defined as consumers who value social justice by using their purchasing power to buy products from companies that use socially conscious practices in their production methods and trade. ${ }^{176}$ This approach uses free market tactics, as opposed to government regulation, to encourage business enterprises to incorporate social and ethical values in their business dealings. ${ }^{177}$

Ethical consumerism is particularly suited to fair trade coffee because it represents the intersection of consumer activism and the goals of fair trade. Consumers with an inclination toward ethical practices support the fair trade coffee movement, which ultimately impacts coffee farmers positively because this increased demand allows farmers to sell their fair trade coffee beans in an expanded market. ${ }^{178}$ Ethical consumerism also helps the sustainability of the fair trade coffee movement because it has staying power, as it has grown even in the face of the late-2007 to 2010 economic recession. ${ }^{179}$

Ethical consumerism is not without its critics. Some argue that while ethical consumerism is a helpful goal for long-term stability of fair trade practices, it is not a viable short-term goal for helping the immediate needs of coffee farmers and their families. ${ }^{180}$ Furthermore, concerns arise regarding the integrity of information that is disseminated to consumers about companies and their ethical practices. ${ }^{181}$ Misleading statements by corporations might serve to undermine the overall success of ethical consumerism as shoppers come to see no essential difference between socalled ethical product choices and actual fair trade goods. ${ }^{182}$

These criticisms point to imperfections in the fair trade process that should be examined and corrected if ethical consumerism is to be effective. However, the underlying idea that consumers have a choice when buying and using products is a core tenet that has encouraged many around the world to promote ethical consumerism within their communities. ${ }^{183}$

175. See Martin Wright, The Ethical Dilemma Facing Consumers, GUARDIAN, http://www.guardian.co.uk/starbucks-ethical-living/ethical-consumer-debate (last visited Jan. 9, 2011).

176. See Draeger, supra note 29 , at 359.

177. See Brown, supra note 54 , at 259.

178. See supra Part II.B.

179. See Wright, supra note 175.

180. See Draeger, supra note 29 , at 362.

181. See id. at 360-61.

182. See id.

183. See Allen, supra note 19. 


\section{A. The First Fair Trade Towns: United Kingdom}

The "fair trade town" movement was born in Europe, ${ }^{184}$ and the first fair trade town in the world was Garstang, England. ${ }^{185}$ Garstang achieved its fair trade status in 2000 with the help of local activist Bruce Crowther, who focused on how fair trade towns lift coffee producers out of poverty. ${ }^{186}$ The primary goal in Garstang was to involve the local community and elicit its help in promoting fair trade, a task that included raising awareness of fair trade practices. ${ }^{187}$ Crowther emphasized the grassroots process the town went through in order to become a fair trade town. ${ }^{188} \mathrm{He}$ also said that he "had to work very, very hard to change attitudes" before the town accepted fair trade town status. ${ }^{189}$ In order to become officially recognized as a fair trade town, Garstang was required to adhere to five established criteria, which included local businesses, schools, and churches agreeing to sell Fairtrade products. ${ }^{190}$ Additionally, the town council passed a resolution supporting Fairtrade. ${ }^{191}$

Today, local recognition of the Fairtrade mark in Garstang has reached ninety percent. ${ }^{192}$ Fairtrade products are sold or served in both private and government establishments, including shops, schools, restaurants, the town council, and the local post office. ${ }^{193}$ The fair trade town movement has spread to over 400 fair trade towns in the United Kingdom. ${ }^{194}$ In fact, the trend has expanded across Europe to over 300 other towns, including Rome, Italy, Copenhagen, Denmark, and Dublin. ${ }^{195}$

Some point out that local farmers view fair trade town status as a threat to their competition in local markets, ${ }^{196}$ but Joe Human of the Cumbria Fair Trade Network explained that both local farmers and those in developing countries face common challenges in competing with large corporations. ${ }^{197} \mathrm{He}$ indicated that the fair trade town effort can be viewed as a harmony between all small-scale farmers: "Fairtrade is not just about a fair price. ... It's also about sustainable farming."198

184. Id.

185. Id.

186. See id.

187. See id.

188. See id.

189. See id.

190. See Jenny Wiggins, Growth in Fairtrade Towns Defies Downturn, FIN. TIMEs, Dec. 18,2009 , at 4 .

191. See id.

192. Allen, supra note 19.

193. Id.

194. See Wiggins, supra note 190.

195. See id.

196. See id.

197. See id.

198. See id. 
Those who have lobbied for their towns to become official fair trade towns have noted the importance of local organization to achieve success. For example, Sophi Tranchell, who chaired the committee to make London a fair trade town in 2008, felt that the fair trade town movement is significant because it "offers an easier route for people to achieve change than traditional politics." 199

\section{B. United States Fair Trade Towns}

Although slower to embrace the grassroots approach to fair trade practices than EU countries, the fair trade town idea has spread to the United States. ${ }^{200}$ Media, Pennsylvania, a small town with a population of approximately 6000 people, became the first official United States fair trade town in 2006. ${ }^{201}$ There were five guidelines Media followed in order to become a fair trade town, goals which were first developed in Europe and have since been imported:

1) The Media Borough [Town] Council passed a resolution supporting Fair Trade and committing to serve Fair Trade coffee and tea at its functions.

2) A range of Fair Trade products are readily available in Media's shops and restaurants.

3) Fair Trade products are used by a number of local work places, such as law offices, and community organizations, such as churches.

4) Media coverage is provided for the fair trade movement in addition to having popular support for the campaign.

5) A local Fair Trade steering group from a diverse representation of institutions is working to ensure continued commitment to Fair Trade Town status. ${ }^{202}$

Today, there are at least twelve more cities across the United States that have joined the fair trade trend, including San Francisco, California. ${ }^{203}$ Additionally, various industry actors are becoming more involved in the process of developing fair trade towns in the United States. ${ }^{204}$ Recently, the Green Mountain Coffee Roasters Foundation provided TransFair USA with

199. Id.

200. See FaIR TRAde Towns USA, http://www.fairtradetownsusa.org/ (last visited Dec. $19,2010)$.

201. DiCamillo, supra note 20.

202. Id.

203. Allen, supra note 19.

204. See Sarah Duxbury, TransFair Gets $\$ 1 M$ to Create Fair Trade Towns, S.F. Bus. TIMES (Mar. 9, 2010, 10:02 AM), http://sanfrancisco.bizjournals.com/sanfrancisco/stories/ 2010/03/08/ daily17.html. 
a one million dollar grant to develop fair trade towns across the country. ${ }^{205}$ This initiative is beneficial for both socially conscious towns and environmentally-friendly corporations. ${ }^{206}$

The United States represents a vast percentage of fair trade products sales, especially coffee ${ }^{207}$ thus, it is in the interest of fair trade activists to encourage more cities in the United States to become official fair trade towns. The idea of a fair trade town initiative being launched as a grassroots effort would likely appeal to many U.S. communities that value participation in local government and political activism on a small scale that is responsive to the needs of individuals or to a community. ${ }^{208}$ The initiative would likely gain support from those who value local autonomy and the ability of a particular community to make a meaningful impact. ${ }^{209}$

\section{SustaINING FAIR TRADE COFFEE Viability}

Coffee in the global market is a serious force, ${ }^{210}$ and how governments and various organizations treat the commodity has a significant impact. However, there is no single solution to help coffee producers. Further, there is no consensus that fair trade practices alone represent a panacea to the problems of pay inequity and a poor standard of life for coffee farmers. ${ }^{211}$ Anecdotal evidence reveals that one small-scale fair trade coffee producer receives $\$ 1.55$ USD per pound for his coffee (approximately ten percent higher than the regular coffee market price), yet after fees for fair trade cooperatives and other taxes, the farmer's net profit is only $\$ 0.50$ USD per pound. ${ }^{212}$ Additionally, although not without possible remedies, there are signs that fair trade's effectiveness to increase profit is limited by growth limitations in the market. ${ }^{213}$

With an eye toward what will be best for those who have the greatest stake in the global coffee market, this Note advocates all efforts designed to help coffee farmers live and work sustainably, healthily, and prosperously, whether those efforts are private or public. One private effort is the Shared Planet scheme developed by Starbucks. ${ }^{214}$ The Shared Planet initiative was

205. See id.

206. See Building Demand for Sustainable Products, GREEN MOUNTAIN COFFEE ROASTERS, http://www.gmcr.com/csr/PromotingSustainableCoffee.aspx (last visited Dec. 19, 2010).

207. See supra Part I.

208. See infra Part VI.B.

209. See id.

210. See supra Part I.

211. See Fieser, supra note 4.

212. Id.

213. See FrIDELL, supra note 12, at 64-65; supra Part II.B.

214. See Starbucks Shared Planet, STARBucks CoFfEe Co., http://www.starbucks.com/ responsibility/learn-more/starbucks-shared-planet (last visited Dec. 19, 2010). 
developed by the corporate coffee giant in an effort to buy more equitable coffee than what it could purchase under the international fair trade coffee scheme. $^{215}$ Because fair trade coffee represents only two percent of the world's supply of coffee, Starbucks desired to satisfy its tremendous demand for coffee in a more equitable manner. ${ }^{216}$ This desire led to Starbucks's development of the Shared Planet standards. ${ }^{217}$ The Shared Planet initiative established a set of criteria, called Coffee and Farmer Equity (C.A.F.E.) standards, which measure sustainable coffee purchases. ${ }^{218}$ The C.A.F.E. standards include a number of social and environmental indicators. $^{219}$ Coffee producers participating in the C.A.F.E. standard scheme must be certified by an independent third party in a manner similar to the certification and fair trade coffee initiative standards used by FLO and others. ${ }^{220}$ In 2008 seventy-seven percent of the coffee purchased by Starbucks (295 million pounds) was from producers certified under the C.A.F.E. standards program. ${ }^{221}$ Private initiatives such as these represent innovative and important inroads to maintaining the viability of efforts to support small-scale coffee farmers. These efforts are another avenue independent of traditional, established fair trade practices to provide coffee producers with access to a fair price for their commodity.

The involvement of corporate entities in fair trade coffee purchases, either through established fair trade certified farms or through self-designed schemes like Shared Planet, are laudable. However, the principles of the fair trade movement and the core motivation of major corporate involvement in fair trade coffee may be at odds. It has been argued that fair trade coffee and corporate practices are, to a certain extent, incompatible because fair trade promotes the interests of small farmers and their empowerment while corporate standards are primarily driven by profitability and are established to elevate a corporation's brand. ${ }^{222}$ Corporate involvement in the fair trade network seemingly benefits the corporation more than farmers in the long run. ${ }^{223}$ For a minimal commitment to fair trade practices, as opposed to a total commitment to purchase solely fair trade coffee, a corporation receives maximum publicity

215. See Benjamin, supra note 121.

216. See id.

217. See id.

218. Starbucks Coffee Co., C.A.F.E. Practices Generic Evaluation Guidelines 2.0 2-19 (2007), available at http://www.scscertified.com/retail/docs/CAFE_GUI_Evaluation Guidelines_V2.0_093009.pdf.

219. See id.

220. See id. at 19.

221. Starbucks Coffee Co., FY 2008 Global Responsibility RePort 57 (2008), available at $\mathrm{http}$ //assets.starbucks.com/assets/fy08-gr-report.pdf.

222. See FRIDELL, supra note 12, at 261.

223. See id. at 262. 
in favor of its practices. ${ }^{224}$ This less than complete commitment to fair trade might be a superficial reaction to criticism of the corporation for not engaging in producer-friendly purchasing practices. ${ }^{225}$

Another critique of corporate involvement in fair trade coffee is the fear that corporate influence will dominate the fair trade market. ${ }^{226}$ The underlying concern is that coffee producers and others involved in the fair trade network would become subservient to the demands and power of a corporation seeking to guide the movement and direct its participants to the corporation's advantage. ${ }^{227}$

There is additional concern that the system of fair trade coffee certification is simply an antidote to consumer guilt and that its price guarantees are set just high enough to assuage feelings of guilt but just low enough to encourage large-scale purchase and consumption. ${ }^{228}$ Essentially, this comes down to a decision between helping to improve modestly the quality of life for many farmers and substantially helping the quality of life for a few farmers. ${ }^{229}$

In light of the various criticisms questioning corporate influence in the fair trade system, it seems that, at this point, maximizing the potential impact non-profit, NGO-led fair trade can have on the coffee trade is the most effective, beneficial approach. As University of California-Berkley researcher Christopher Bacon indicates, "Fair Trade is still, and will remain, a better deal for farmers," ${ }^{230}$ as opposed to letting market forces or the private sector decide the best standards for fair trade coffee. ${ }^{231}$

The possibility of an expansion of fair trade coffee practices may increase the movement's effectiveness. These expansions include not only an increased number of certified farms, but also more varied programs helping producers secure loans, build infrastructure, and undertake other sustainable investments. ${ }^{232}$

There are various ways to stimulate support for fair trade coffee, but this Note focuses primarily on the way fair trade practices can influence market forces, which increase demand for fair trade coffee. This is not to say, however, that a free-market approach is the best route to achieving such a goal; on the contrary, perhaps a particularly effective and more fully comprehensive approach would use regulatory measures in combination with ethical consumerism ${ }^{233}$ in order to spur market activity. Ethical

\footnotetext{
224. See id.

225. See id.

226. See id. at 262-63.

227. See id.

228. See Richardson, supra note 34 .

229. See id.

230. Fieser, supra note 4.

231. See Richardson, supra note 34.

232. See supra Part II.

233. See supra Part V.
} 
consumerism informs the purchaser that there are important social and ethical considerations based on their purchases; armed with that information, a knowledgeable consumer will tend to buy those goods and services that incorporate ethical values. ${ }^{234}$ An effective campaign to educate consumers and to spur them to purchase in an ethical manner should increase demand for fair trade coffee. ${ }^{235}$ Thus, the recommendations offered in this Note emphasize strengthening regulatory mechanisms used by the fair trade network and organizations like FLO in conjunction with measures, both local and national, designed to stimulate ethical activity in the market.

\section{A. U.S. Domestic Policy Recommendations}

\section{Emulating the Schmidt Report}

U.S. congressional responses to the historical plight of small-scale coffee farmers $^{236}$ are admirable in that they demonstrate sensitivity to the issues facing coffee-producing communities. They also illustrate that the United States is aware of the problems coffee-producing communities deal with and that these problems can have a significant impact on both the U.S. economy and international relations. ${ }^{237}$ Unfortunately, these resolutions serve merely as a half-hearted effort for meaningful change in the fair trade coffee movement. These resolutions seem to be of rather limited effectiveness," ${ }^{238}$ and "[a]lthough the government is a major consumer of coffee, it is doubtful that its commitment to curb inequity offered in these governmental measures would have a significant effect on producers."239 In reality, Congress could do much more to advocate on behalf of those directly benefitting from fair trade practices. For example, Congress could work with other international organizations involved in the global coffee trade. $^{240}$ Congress should examine its obligations through trade agreements and treaties and consider the many options available that benefit the coffee-

234. See Draeger, supra note 29, at 359.

235. See generally supra Part V (detailing the fair trade town phenomenon).

236. See supra Part III.B.

237. See generally Part III (discussing concerns coming from both International Coffee Agreements in the past as well as the House Resolution recognizing, to a limited extent, the benefits of fair trade coffee).

238. See Shannon, supra note 2, at 188.

239. Id. Indeed, it is argued that the government's role as an ethical consumer is not enough and that stronger regulations in the form of a reinvented ICA would be more effective. Id. at 188-89.

240. See generally Todd Mumford, Note, Voluntary International Standards: Incorporating "Fair Trade" Within Multilateral Trade Agreements, 14 SW. J. L. \& TRADE AM. 171 (2007) (detailing international trade agreements involving fair trade coffee between the United States and other countries). 
producing community. ${ }^{241}$ Specifically, the United States should be cognizant of treaty agreements since they have historically been an important aspect of the fair coffee trade movement. ${ }^{242}$ Participating in binding agreements with other countries, especially those heavily involved in the production of coffee, demonstrates a serious commitment to positive action in favor of the fair trade movement. Several ideas for crafting agreements that benefit fair trade coffee participants have been proffered ${ }^{243}$ and should be reconsidered by Congress.

In addition to the international obligations Congress should consider when committing to fair trade coffee practices, there are significant strides the United States can make domestically. This Note advocates a definitive document promulgated by Congress in the style of the EU's Schmidt Report. ${ }^{244}$ This document should include detailed steps that the government can take to examine the future of fair trade coffee and how it affects the United States.

One major advantage of the Schmidt Report is that it lists several approaches the EU should take in order to increase support for the fair trade movement; furthermore, the Report contains specific criteria important to an effective fair trade regime. ${ }^{245}$ The Schmidt Report is detailed and provides specific examples of the major problems facing the future of fair trade coffee. ${ }^{246}$ A cursory comparison between the Schmidt Report and U.S. House Resolution $349^{247}$ reveals that the latter could benefit from greater specificity and substance. Perhaps because the United States is not a major coffee-producing country, or perhaps because of a tendency toward free market policies, ${ }^{248}$ Congress has been resistant to address the coffee crisis and fair trade coffee in any meaningful way since the last ICA in the $1980 \mathrm{~s}^{249}$ It is ultimately in the interest of the United States to support the growth of fair trade coffee because the United States is one of the world's greatest consumers of coffee, ${ }^{250}$ is a major player in the international coffee trade, and has many private corporations closely tied to the coffee industry. ${ }^{251}$ This fragile balance of interests requires a level of regulation and stability that fair trade coffee can effectively provide.

A document promulgated by Congress akin to the EU's Schmidt

241. Id.

242. See id.; supra Part III.A.

243. See Mumford, supra note 240 at 184-91.

244. See supra Part IV.A.

245. See European Parliament Resolution on Fair Trade and Development, supra note 17, II 2(a)-(k).

246. See id.

247. See H.R. Res. 349, 108th Cong. (2003).

248. See Draeger, supra note 29, at 345.

249. See supra Part III.A.

250. See Shannon, supra note 2, at 170.

251. See supra Part III.C. 
Report would be an important first step in the process of paying meaningful attention to fair trade coffee. A more concrete and substantial step than the promulgation of a document would be legislation mandating fair trade certified coffee in federal government buildings and at meetings. An American version of the Schmidt Report could serve as a precursor to such legislation while simultaneously serving to educate both the public and the government on the significance and advantages of fair trade coffee. The Schmidt Report conveys considerable information about the fair trade coffee movement, ${ }^{252}$ and a U.S. version should, at a minimum, raise interest in the fair trade coffee movement. Ultimately, the United States should take the Schmidt Report as a guideline for developing its own version of a fair trade coffee promulgation that emphasizes the United States' role in the international coffee trade and the importance of fair trade coffee to U.S. interests.

\section{Reaffirmation of a Uniform Labeling Initiative}

Fair trade is not a perfect system, and the various labeling initiatives launched by international fair trade organizations sometimes confuse consumers or complicate the buying process. ${ }^{253}$ Also, with such a multitude of labels bearing different certifications and guarantees, unscrupulous companies may exploit the lack of uniformity in the scheme. ${ }^{254}$ There are many different types of labels available for fair trade products, including multiple labels associated with fair trade coffee. ${ }^{255}$ Part of the problem stems from labels that marginally address fair trade coffee practices, yet appear to be associated with fair trade. ${ }^{256}$ Such labels are generally geared toward shade-grown coffees or bird-friendly growing practices. ${ }^{257}$ While they may be important in and of themselves, they unnecessarily complicate the buying process. ${ }^{258}$

This fragmented system is not optimal. ${ }^{259}$ In order to create increased demand for fair trade coffee by way of consumer awareness and education, a unified labeling scheme is required. Empowering the consumer to trust a meaningful label will be one of the most effective tools in increasing demand for fair trade coffee. Others have advocated a uniform labeling scheme, ${ }^{260}$ and this Note affirms that consumers will be most easily

252. See European Parliament Resolution on Fair Trade and Development, supra note 17, กा $\mathrm{A}-\mathrm{X}$.

253. See supra Part II.B.

254. See Draeger, supra note 29 , at $360-61$; supra Part V.

255. See Brown, supra note 54, at 262.

256. See generally id. (explaining various labels and their significance).

257. See id.

258. See id.

259. See id.

260. See id. at 279; Mumford, supra note 240, at 190. 
informed about and trustworthy of a single label signifying an accepted standard. This idea seems to be coming to fruition; whereas in past years FLO member countries used their own national labels, FLO has gradually introduced a uniform label for many countries. ${ }^{261}$ The United States, however, continues to use its own unique label. ${ }^{262}$

\section{B. Local Government Efforts}

The fair trade town trend seen throughout Europe has been effective in raising local consumers' awareness regarding fair trade coffee practices. $^{263}$ The concept was not accepted without some convincing from grassroots advocates, ${ }^{264}$ but the fair trade town idea has remained successful by weathering the recent economic recession and is now in a state of growth. ${ }^{265}$

As mentioned, the United States is not ignorant of Europe's fair trade town phenomenon. ${ }^{266}$ It has at least a dozen cities that are certified fair trade, a trend that also seems to be growing. ${ }^{267}$ Increasing the number of fair trade towns all over the world, specifically in the United States, given its high demand for coffee, would greatly benefit the fair trade coffee movement. A fair trade town is an innovative idea to support the fair trade coffee movement because it seeks to educate and involve people on an individual level within the consumer's own community. The fair trade town idea represents a relatively simple and direct way citizens can become involved in the coffee trade, even if on a small scale. However, in the aggregate, small-scale involvement becomes significant.

Fair trade towns are also a unique way in which local government can become involved both within the coffee industry and constituents' lives. A local government that passes a fair trade bill not only adds to the potential demand for fair trade products but also actively responds to the desires of socially conscious consumers who desire their purchases to be ethical and have a beneficial impact on countless others in an international economy. Local government action of this sort also serves to educate consumers and give a governmental imprimatur to the effectiveness of the fair trade movement. Fair trade towns should be encouraged as a way to effectuate change from grassroots advocacy.

In addition to local government acting conscientiously, the fair trade

261. See About the Mark, FAIRTRADE LABELLING ORGS. INT'L, http://www.fairtrade.net/ about_the_mark.html (last visited Dec. 19, 2010).

262. See id.

263. See supra Part V.A.

264. See Wiggins, supra note 190.

265. See id.

266. See supra Part V.B.

267. See Allen, supra note 19. 
town initiative aligns with the concept of ethical consumerism. ${ }^{268}$ Ethical consumerism acts on an individual level and gives the consumer a sense of power, even if that occurs at the grocery store checkout. ${ }^{269}$ Various labels on coffee products tend to dilute the strength of what a meaningful label actually purports to do. The lack of fair trade coffee being offered in many local stores has also likely contributed to the slow growth of purchases. ${ }^{270}$ The addition of a fair trade town initiative in a community would greatly reduce consumer confusion, increase consumer awareness of the benefits of fair trade products, and increase the availability of fair trade coffee and other fair trade products. Armed with information, choice, and a desire to act ethically, a consumer is likely to act ethically and purchase fair trade coffee. ${ }^{271}$ The motivation to purchase fair trade coffee can only be bolstered by a system supported on a grassroots level.

\section{CONCLUSION}

When examining what practices or schemes will be most successful in increasing support for the fair trade movement, remembering the ultimate beneficiaries of the fair trade movement is imperative. Initiatives such as ethical consumerism make the conscientious purchaser feel good about their purchases by becoming part of a something larger. When ethical consumerism is used to foster support for fair trade, it can help those less advantaged by creating sustainable communities for coffee producers. People involved in the laborious farming of the coffee plant have been greatly exploited. Many of those hard working farmers who are not yet participating in fair trade coffee practices are still exploited today. The fair trade coffee movement was established in order to decrease inequalities and has done much to improve the equities among those in the international coffee trade. However, despite the inequities, there is still much to be done.

Some statistics from Mexico illustrate the existing abuses within the coffee trade. Mexico, the world's fifth largest producer of coffee, is home to approximately 280,000 coffee growers, around 200,000 of whom are small-scale farmers. ${ }^{272}$ Over sixty percent of these farmers are indigenous. ${ }^{273}$ Many coffee producers in Mexico reside in communities lacking essential infrastructure like hospitals, electricity, schools, improved

268. See supra Part V.

269. Id.

270. See supra Part II.B.

271. See supra Part V. It may be important to note that the concept of ethical consumerism becomes more complicated in the face of certain socio-economic realities like the inability to pay slightly higher prices for fair trade coffee. The idea is best applied where, all other things being equal and with proper information, a consumer will support others and choose fair trade coffee instead of alternatives.

272. FRIDELL, supra note 12, at 174-75.

273. Id. 
roads, or running water. ${ }^{274}$ Approximately eighty-four percent of the places in Mexico where coffee is a major agricultural crop have very high poverty indicators. ${ }^{275}$ Communities like these that are wholly dependent on the crop of the coffee plant demonstrate the promise of an effective fair trade coffee movement. When these Mexican coffee producers are certified fair trade farmers, they are paid equitably, and along with those with whom they deal, reinvest in the community to ensure the long-term viability of the producers and the places in which they operate.

Focus on the coffee producer must remain steadfast when deciding how best to approach the sustained viability of the fair trade coffee movement. Fair trade has the potential to benefit various parties: consumers desiring to make ethical purchasing decisions, legislatures mindful of the impact their decisions have on international trade, or corporations hoping to improve their image and brand in the face of criticism. However, the proper focus must remain on the most deserving beneficiaries of the fair trade movement - the small-scale producers - for whom the movement was created. If other interests are permitted to dominate the direction of fair trade coffee practices, the future of the fair trade movement is uncertain. If fair trade remains committed to its core principles, however, its future is bright, and its sustainability is achievable. 
